\title{
Self-handicapping strategies for learning of preservice teachers
}

\author{
Estratégias autoprejudiciais à aprendizagem \\ de professores em formação
}

Danielle Ribeiro GANDA ${ }^{1}$

Evely BORUCHOVITCH ${ }^{1}$

\begin{abstract}
The aim of the study was to investigate self-handicapping strategies applied by students in an academic context and to analyze the relationship between the use of these strategies and the students' gender, age and course year. The sample consisted of 164 students of both genders aged 18 to 48 years and enrolled in the second and fourth years of the undergraduate program in pedagogy at Brazilian public universities. The data were collected through open-ended questions and a self-reported Likert scale instrument. Students reported applying several self-handicapping strategies, such as procrastination and not reading the recommended texts. Young students and women reported a more frequent use of these strategies. The importance of identifying the self-handicapping behavior of college students is discussed in this article.
\end{abstract}

Keywords: Higher education; Procrastination; Teacher education.

\section{Resumo}

A presente pesquisa tem como objetivo investigar as estratégias autoprejudiciais empregadas por alunos em contexto acadêmico, explorando as relações entre o uso dessas estratégias e o gênero, idade e etapa do curso. A amostra foi composta por 164 estudantes universitários de ambos os gêneros, com idade entre 18 e 48 anos, matriculados no $2^{\circ}$ e no $4^{\circ}$ ano de cursos de Pedagogia em universidades públicas brasileiras. Os dados foram coletados por meio de questões abertas e de uma escala de autorrelato do tipo Likert. Os estudantes relataram empregar diversas estratégias autoprejudiciais, como procrastinar e não fazer a leitura dos textos recomendados. Os alunos mais novos e as mulheres relataram uso mais frequente dessas estratégias. Discute-se a importância de se identificar os comportamentos autoprejudiciais de universitários.

Palavras-chave: Ensino superior; Procrastinação; Formação de professores.

$\nabla \nabla \nabla \nabla$

${ }^{1}$ Universidade Estadual de Campinas, Faculdade de Educação, Departamento de Psicologia Educacional. R. Bertrand Russell, 801, Cidade Universitária Zeferino Vaz, 13083-865, Campinas, SP, Brasil. Correspondência para/Correspondence to: E. BORUCHOVITCH. E-mail: <evely@unicamp.br>.

Article based on the master dissertation of D.R. GANDA, intitled "Causal attributions and self-handicapping strategies of students in a teacher training course". Universidade Estadual de Campinas, 2011.

Acknowledgments: The authors are thankful for the support of the Conselho Nacional de Desenvolvimento Científico and Tecnológico (Process no 302464/2010-7), and Coordenação de Aperfeiçoamento de Pessoal de Nível Superior (Process n 018/2007). 
The term self-handicapping was created and first presented to the scientific community in 1978 by the American researchers Berglas and Jones. According to the authors, self-handicapping strategies are strategies (excuses and behaviors) created by a person while performing a task that is important for them while not feeling capable of performing it (Berglas \& Jones, 1978; Harris, Snyder, Higgins, \& Schrag, 1986; Kolditz \& Arkin, 1982). Self-handicapping strategies can be used in many contexts, such as management, sports and in academia. The frequent use of these strategies jeopardizes performance and interferes with success (Finez \& Sherman, 2012; McCrea, Hirt, Hendrix, Milner, \& Steele, 2008; Smith, Hardy, \& Arkin, 2009).

In the first Brazilian study on this theme (Zanatto, 2007), the term self-handicapping strategies was translated and adapted to Portuguese as "estratégias autoprejudicadoras" because the strategies refer to actions performed by the individuals themselves that can create difficulties or barriers (handicaps) toward the effective performance of a given task (Berglas \& Jones, 1978). In a later study (Ganda, 2011), the term was analyzed by college professors from the fields of psychology and education and by a reviewer with expertise in the Portuguese language. It was agreed that "estratégias autoprejudiciais" would be the most appropriate translation for the English term and would best express the original idea which refers to the impairment of oneself.

Studies reveal that the insecurity of individuals in relation to their capability to perform a task leads them to engage in actions that can jeopardize their performance (Harris et al., 1986; Kolditz \& Arkin, 1982). The mechanism of creating obstacles to the execution of a task is used by individuals to protect their self-esteem so that a possible failure could be attributed to these impediments and not to their lack of skill. A student who only studies one day before a test and an athlete who does not perform the recommended technical training are examples of individuals using self-handicapping strategies (Berglas \& Jones, 1978). In these cases, the lack of prior study and inadequate training can be used as excuses for a low grade on the test or a defeat in a competition. However, it was noted that in case of good results success becomes more evident because it was achieved despite inadequate preparation. Therefore, the use of self-handicapping strategies has a dual function. They can minimize the perception of inability in face of a failure, and they can increase the feeling of self-worth in the case of success achieved without the adequate investment of effort (Berglas \& Jones, 1978; Hirt, Deppe, \& Gordon, 1991).

According to Leary and Shepperd (1986), self-handicapping strategies can be divided into two types: behavioral and claimed self-handicaps. The first type refers to obstacles created by individuals who will endanger their performance. In the academic context, examples include talking during class, not completing the tasks assigned by the professor and not preparing for the presentation of an oral assignment. The second type includes students' claims regarding the impediments they will face in performing the task, such as the many other commitments in addition to college that prevent them from studying or simply because they are too nervous to take a test. Although similar, these two types of strategy differ in terms of the harm to academic performance and are related to external judgment (Gadbois \& Sturgeon, 2011; Hirt et al., 1991; Leary \& Shepperd, 1986).

Behavioral self-handicaps are actions that can effectively undermine the performance of an activity (Hirt et al., 1991; Leary \& Shepperd, 1986). When students do not read the assigned theoretical material or attend a party the night before a test, they diminish their opportunities to learn and obtain a good grade. However, if they prepare properly and only verbalize to express anxiety regarding a test, the behavior does not necessarily mean that they will perform worse.

Behavioral self-handicaps differ from claimed self-handicaps because the former can be observed and therefore are more compelling "excuses" for failure (Hirt et al., 1991; Leary \& Shepperd, 1986). Thus, behavioral self-handicaps are more likely to be punished. If a student talks during class and does not perform the assigned reading and tasks, the 
professor tends to believe that distraction and lack of effort are the reasons for the student's poor performance. However, if the student reports, for instance, that he or she is undergoing personal problems, the professor may or may not believe the student but is likely to be more understanding and require less from the student than the professor would under regular circumstances.

In the academic context, self-handicapping strategies typically manifest themselves by the abuse of alcohol and drugs, procrastination and noncompletion of assignments, not reading the theoretical material, lack of attention during class and insufficient preparation for examinations (Berglas \& Jones, 1978; Kolditz \& Arkin, 1982; Schraw, Wadkins, \& Olafson, 2007; Smith et al., 2009). A person's attitude is considered self-handicapping when it hides a feeling of insecurity and fear of failure in a way that actions and omissions function as a plausible excuse in the event of negative feedback at school, for example, failing a course (Harris et al., 1986; Schwinger \& Stiensmeier-Pelster, 2011).

Procrastination is one of the most frequently investigated behavioral self-handicaps in the academic context. It is defined as the action of delaying the performance of an activity (Ferrari \& Tice, 2000; Lay, Knish, \& Zanatta, 1992; Leondari \& Gonida, 2007; Schraw et al., 2007). For example, students procrastinate when they study only the day before the test or perform an extensive assignment close to the deadline. Typically, procrastination harms physical and psychological well-being and results in poor academic performance. Nevertheless, individuals continue to use this strategy because their insecurity increases as a result of their lack of preparation, which increases their chances of failure and makes them believe that they are incapable of performing the tasks and being academically successful (Ferrari \& Tice, 2000; Martin, Marsh, \& Debus, 2001).

Recently there have been several international studies on self-handicapping strategies in the academic context. The studies have investigated the relationship between the use of these strategies and motivation (Graham, Tisher, Ainley, \& Kennedy,
2008; Hirt, McCrea, \& Boris, 2003; McCrea, 2008), self-esteem (Seli, Dembo, \& Crocker, 2009), performance (Martin et al., 2001; McCrea et al., 2008; Schraw et al., 2007; Smith et al., 2009) and emotions (Alter \& Forgas, 2007; Coudevyle, Martin Ginis, Famose, \& Gernigon, 2009; Hendrix \& Hirt, 2009). Generally, the use of self-handicapping strategies is associated with low self-esteem, reports of psychological symptoms (such as stress and anxiety), poor academic performance and lack of organization and academic goals (Hendrix \& Hirt, 2009; Martin et al., 2001; McCrea, 2008; Schwinger \& Stiensmeier-Pelster, 2011). Regarding the differences between genders, the data indicate that women evaluate self-handicapping behaviors more negatively than men and use these strategies less often (Hirt et al., 2003; Hirt, McCrea, \& Kimble, 2000; McCrea et al., 2008).

In the Brazilian context, only one study on the topic was found, which aimed to analyze the relationship between the perception of the classroom structure, the adoption of achievement goals and the use of self-handicapping strategies by college students (Zanatto, 2007). The results showed that the performance goal, related to the student focusing on performance and comparison with peers, was positively associated with the use of self-handicapping strategies. According to the literature, students who use these strategies are more concerned with the social evaluation of their performance than with the acquisition of new knowledge (Alter \& Forgas, 2007; Hendrix \& Hirt, 2009; Martin, Marsh, Williamson, \& Debus, 2003).

Studies on professors suggest that professors who are more aware of the cognitive and motivational variables that interfere with their own learning possibly have better knowledge and skills to address the learning process of their students (Zimmerman, 2006; Zimmerman \& Schunk, 2004). Thus, for this study we selected a sample of students from an undergraduate program for preservice teachers in the expectation that the identification of behavioral self-handicaps to their learning process can contribute to improve them both as college students and as future teachers.

Moreover, considering the important implications that the use of self-handicapping 
strategies have for learning and the need for further research on this topic, the goals of this study were to investigate the self-handicapping strategies used by college students in a pedagogy program and to investigate possible relationships between the reported use of these strategies and variables such as gender, age and course year.

\section{Method}

\section{Participants}

The study was based on a convenience sample that consisted of 164 students in the pedagogy programs of Brazilian public universities. Of the participants, 147 (89.63\%) were female and $17(10.37 \%)$ male. Regarding the course year, 61 (37.20\%) were from the second year and 103 $(62.8 \%)$ were from the fourth year. The mean age of the students was 23.76 years, with the following divisions by age group: 53 (32.32\%) between 18 and 20 years, 97 (59.15\%) between 21 and 30 years, and 14 (8.54\%) between 31 and 48 years.

\section{Instruments}

Problem situation for assessing self-handicapping strategies of college students

The instrument consisted of a hypothetical problem situation that was developed based on the literature and that addressed the situation of a student who uses self-handicapping strategies in the classroom. Based on this scenario, the participants were asked to reflect on their conduct in college and then answer four questions: two objective questions (with "yes" and "no" options) and two open-ended questions. More precisely, the students were to report whether they use such strategies, which ones they use and whether they find it important to reflect on the actions that hinder their learning.

\section{Self-handicapping strategies scale}

The Likert scale created by the authors for 420 this study consisted of 24 items related to the use of self-handicapping strategies in academic settings. There were four answer options which ranged from 1 (It has nothing to do with me) to 4 (It describes me really well). The total score could vary from 24 to 96 points, whereby the higher the score, the more frequent the use of self-handicapping strategies by students.

Initially, the items of the instrument were organized in three subscales, which were constructed according to their content in accordance with the literature (Hirt et al., 2003; Stipek, 1988; Urdan, 2004; Zanatto, 2007). The first subscale referred to problems with time management (e.g., "Some students only study the day before the exam. In case of failure, they claim that they did not have enough time to study all of the subject content"). The second subscale was related to failure to control attention (e.g., "Some students keep using their cell phones during class. In case of a bad result, they claim they did not understand the professor's explanation"). The third subscale was related to problems associated with the preparation for an activity (e.g., "Some students do not prepare properly for an oral presentation and then become very nervous at the time of the presentation. In the case of a poor performance, they claim they were hindered by their nervousness"). Each subscale contains 12, 5 and 6 items, respectively.

Preliminary psychometric analyses were performed and indicated high levels of internal consistency for the total scale $(\alpha=0.85)$ and for the subscale "problems with time management" $(\alpha=0.80)$ and acceptable Cronbach's alpha values for the subscales "failure to control attention" $(\alpha=0.63)$ and "problems preparing an activity" $(\alpha=0.62)$ (Prieto \& Muñiz, 2000). Studies on the factor structure of the scale are being conducted (Boruchovitch \& Ganda, 2013).

The two instruments used in this study were developed in accordance with theoretical assumptions concerning the topic (Hirt et al., 2003; Stipek, 1988; Urdan, 2004; Zanatto, 2007). Pilot studies, which greatly contributed to the refinement of the items and questions, were previously conducted. 
First, the coordinators of the undergraduate program in pedagogy from two Brazilian public universities were contacted and each received a letter requesting permission to conduct the study. Then, the project was submitted to and approved by the Research Ethics Committee of the School of Medical Sciences of the Universidade Estadual de Campinas, Protocol no 1195/2009. The study was then presented to the students and those who agreed to participate were asked to sign in duplicate an Informed Consent. It was emphasized that participation was voluntary and that the identification of the universities and students would not be disclosed. Data collection was performed collectively by appointment and according to the convenience of the participants and institutions. First, the students answered open-ended questions and then proceeded to the Likert scale instrument. The average time spent to answer the questionnaires was 40 minutes.

Open-ended questions were assessed using content analysis. A categorization system including all types of behaviors and explanations mentioned by the participants was developed. The categories were operationally defined and presented to three independent evaluators, who performed the analysis of approximately $40 \%$ of the total answers of the sample, randomly chosen. The percentage of agreement between the assessment made by the researcher and the evaluators ranged from $85 \%$ to $100 \%$. Quantitative data were examined according to the procedures of descriptive (percentile, median, percentage) and non-parametric inferential (MannWhitney $U$ test, Kruskal-Wallis test, Spearman's correlation) statistics because the Shapiro-Wilk test revealed absence of a normal distribution of data.

\section{Results}

In the open-ended instrument, the first question inquired whether students had attitudes that hindered their learning and, if so, which ones. Most students ( $\mathrm{N}=116 ; 70.73 \%)$ answered yes, whereas 48 (29.27\%) said no. Of the participants who reported using self-handicapping strategies, $70(60.34 \%)$ described only one strategy, 34
(29.32\%) mentioned two and $12(10.34 \%)$ indicated three.

"Procrastination" was the most frequently mentioned strategy with $31.03 \%(N=54)$ of responses, followed by "Lack of reading theoretical texts" with $20.69 \%(N=36)$ and "Problems with time management" with $14.95 \%(\mathrm{~N}=26)$. Other self-handicapping strategies mentioned included "Failure to control attention" ( $N=25 ; 14.37 \%)$, "Unconcern with school attendance" ( $\mathrm{N}=17$; $9.77 \%)$, "Lack of effort in the performance of activities" ( $\mathrm{N}=9 ; 5.17 \%)$ and "Complaints relating to physical and emotional states" ( $N=7 ; 4.02 \%)$. Interestingly, among the response categories described by the sample, most examples are behavioral self-handicaps and only the last one, whose occurrence was the lowest, refers to stated self-handicaps.

The next question addressed the importance of reflecting on the harmful attitudes toward learning. Most students ( $N=159 ; 96.95 \%)$ said that reflecting on their actions is crucial and the reasons mentioned were "change in behavior" $(\mathrm{N}=81 ; 50.94 \%)$, "improvement in learning" $(\mathrm{N}=37 ; 23.27 \%)$, "improvement in academic performance" ( $\mathrm{N}=30 ; 18.87 \%)$ and "professional enhancement" ( $N=9 ; 5.66 \%)$. Among the students who answered yes to the question, two students (1.25\%) did not provide a justification.

The data obtained by the scale for selfhandicapping strategies were initially submitted to a descriptive analysis. Table 1 shows the lowest and highest scores obtained by participants, i.e. 24 and 59 , respectively, with a Standard Deviation of 9.05 . Strategies associated with "problems with time management" were the most frequently cited by the sample.

In the analysis of the scale means in relation to age group, the Kruskal-Wallis test revealed that students up to the age of 30 obtained significantly higher scores on the total scale and subscales of failure to control attention and lack of preparation. Participants aged between 21 and 30 years exhibited a higher incidence of the reported use of self-handicapping strategies related to problems with time management. These results are summarized in Table 2. 
Table 1

Mean, Standard Deviation (SD) and maximum and minimum score in the scale and subscales of self-handicapping strategies

\begin{tabular}{lcrrrr}
\hline Self-handicapping strategies & $N$ & Mean & SD & Minimum & Maximum \\
\hline Problems with time management & 164 & 20.24 & 5.62 & 12.0 & 35.0 \\
Failure to control attention & 164 & 6.79 & 2.10 & 5.0 & 17.0 \\
Problems related to the preparation for an activity & 164 & 9.40 & 2.47 & 6.0 & 17.0 \\
Total self-handicapping strategies & 164 & 38.07 & 9.05 & 24.0 & 59.0 \\
\hline
\end{tabular}

Table 2

Difference in means in the scale and subscales of self-handicapping strategies in relation to age group

\begin{tabular}{|c|c|c|c|c|c|c|c|}
\hline \multirow{3}{*}{ Self-handicapping strategies } & \multicolumn{6}{|c|}{ Age group } & \multirow{3}{*}{$p$-value* } \\
\hline & \multicolumn{2}{|c|}{$\leq 20$} & \multicolumn{2}{|c|}{$21-30$} & \multicolumn{2}{|c|}{$>30$} & \\
\hline & Mean & SD & Mean & SD & Mean & SD & \\
\hline Problems with time management & 19.34 & 5.54 & 21.12 & 5.75 & 17.57 & 3.39 & 0.031 \\
\hline Failure to control attention & 6.83 & 1.75 & 6.97 & 2.34 & 5.43 & 0.65 & 0.009 \\
\hline Problems related to the preparation for an activity & 9.43 & 2.05 & 9.63 & 2.71 & 7.71 & 1.33 & 0.020 \\
\hline Total self-handicapping strategies & 37.26 & 8.39 & 39.40 & 9.53 & 31.93 & 4.30 & 0.010 \\
\hline
\end{tabular}

Note: ${ }^{*} p$-value refers to the Kruskal-Wallis test for comparison of variables between three groups.

SD: Standard Deviation.

Table 3

Correlations of scores in the scale and subscales of self-handicapping strategies in relation to age

\begin{tabular}{lccc}
\hline Self-handicapping strategies & $\rho$ & $p$ & $n$ \\
\hline Problems with time management & 0.051 & 0.509 & 164 \\
Failure to control attention & -0.245 & 0.001 & 164 \\
Problems related to the preparation for an activity & -0.162 & 0.037 & 164 \\
Total self-handicapping strategies & -0.057 & 0.461 & 164 \\
\hline
\end{tabular}

Note: $p$ : Spearman's correlation coefficient; $p$ : $p$-value; $n$ : number of individuals $(n=164)$.

Additionally, correlations between age and scale scores were estimated (Table 3). A low and negative significant correlation of the variable age with scores of the subscales "failures in attention control" and "problems related to the preparation of the activity" was found. The results indicated that the older the student, the less frequent is the use of self-handicapping strategies in the academic context.

When comparing the scale means with the variable gender, the Mann-Whitney $U$ test indicated significant differences (Table 4). In general, women affirmed using self-handicapping strategies more frequently, particularly strategies concerned with "problems with time management". With regard

422 to strategies associated with attention control and preparations for an activity, both men and women reported similar use.

No significant differences were found when comparing the means and course year (Table 5).

\section{Discussion}

This study aimed to analyze the selfhandicapping strategies of college students in a pedagogy program and examine the relationship between the reported use of these strategies and the variables gender, age and course year. Generally, most participants reported the use of selfhandicapping behaviors in the academic context such as procrastination, not reading theoretical 
Table 4

Difference in means in the scale and subscales of self-handicapping strategies in relation to gender

\begin{tabular}{|c|c|c|c|c|c|}
\hline \multirow{3}{*}{ Self-handicapping strategies } & \multicolumn{4}{|c|}{ Gender } & \multirow{3}{*}{$p$-value } \\
\hline & \multicolumn{2}{|c|}{ Female } & \multicolumn{2}{|c|}{ Male } & \\
\hline & Mean & SD & Mean & SD & \\
\hline Problems with time management & 20.57 & 5.62 & 17.41 & 4.86 & 0.021 \\
\hline Failure to control attention & 6.84 & 2.11 & 6.41 & 2.06 & 0.213 \\
\hline Problems related to the preparation for an activity & 9.52 & 2.48 & 8.41 & 2.15 & 0.087 \\
\hline Total self-handicapping strategies & 38.59 & 8.95 & 33.65 & 9.01 & 0.019 \\
\hline
\end{tabular}

Note: " $p$-value refers to the Mann-Whitney U test for comparison of variables between two groups.

SD: Standard Deviation.

Table 5

Difference in means in the scale and subscales of self-handicapping strategies in relation to year in the undergraduate program

\begin{tabular}{|c|c|c|c|c|c|}
\hline \multirow{3}{*}{ Self-handicapping strategies } & \multicolumn{4}{|c|}{ Year in the undergraduate program } & \multirow{3}{*}{$p$-value* } \\
\hline & \multicolumn{2}{|c|}{$2^{\text {nd }}$ year } & \multicolumn{2}{|c|}{$4^{\text {th }}$ year } & \\
\hline & Mean & SD & Mean & SD & \\
\hline Problems with time management & 19.30 & 5.17 & 20.81 & 5.82 & $p=0.118$ \\
\hline Failure to control attention & 6.72 & 1.97 & 6.83 & 2.19 & $p=0.950$ \\
\hline Problems related to the preparation for an activity & 9.13 & 2.33 & 9.56 & 2.55 & $p=0.339$ \\
\hline Total self-handicapping strategies & 36.77 & 8.49 & 38.84 & 9.32 & $p=0.178$ \\
\hline
\end{tabular}

Note: " $p$-value refers to the Mann-Whitney U test for comparison of variables between two groups.

SD: Standard Deviation.

texts, failure to organize study time, lack of attention in class, unconcern with school attendance and lack of effort. According to the literature, this result was expected and has important educational implications because these behaviors can affect learning and jeopardize student performance (Gadbois \& Sturgeon, 2011; Leary \& Shepperd, 1986; Leondari \& Gonida, 2007; Schwinger \& Stiensmeier-Pelster, 2011).

Similarly to the results of other studies, among the self-handicapping strategies cited by the participants in this study, procrastination was predominant (Ferrari \& Tice, 2000; Schraw et al., 2007). Procrastination is a harmful behavior with respect to personal health and personal achievement because of the increased stress and anxiety it causes (Ferrari \& Tice, 2000; Tice \& Baumeister, 1997; Schraw et al., 2007). Moreover, it has a harmful effect on learning since time is wasted instead of being devoted to increasing one's knowledge of the study materials (Martin et al., 2001; Tice \& Baumeister, 1997). Thus, it is essential that further research focuses on the reasons students provide to explain their procrastination.

In the data analysis of the scale, the comparison of means in relation to gender indicated no significant differences in the use of handicapping strategies related to attention control and preparation for activities. Conversely, regarding problems with time management, women reported a more frequent use of these strategies than their male peers. These results do not agree with those of previous studies which found that men typically exhibit behavioral self-handicaps more often than women (Hirt et al., 2000; Hirt et al., 2003; McCrea, 2008). However, due to the small sample of male students, it is essential that further investigations be conducted with an equal number of participants from both genders.

The analysis of the use of these strategies concerning age showed that young students exhibit behavioral self-handicaps more frequently than older colleagues. No significant differences were observed regarding the course year. Unfortunately, 
no studies that specifically compare the frequency in the use of these self-handicapping strategies among college students of different ages were found in the literature. However, studies reveal that these behaviors occur regularly during all of the years of college education and suggest that both freshmen and seniors display behaviors that are unfavorable to their learning (Gadbois \& Sturgeon, 2011; Seli et al., 2009; Smith et al., 2009). Given the importance of a more precise analysis to develop proposals for psycho-pedagogical intervention to aid these students, we recommended that further studies investigate the use of self-handicapping strategies in academic context based on equivalent samples of students by age group and course year as well as students from different fields of knowledge, such as exact and biological sciences.

It was interesting to note that the study participants, despite reporting the use of selfhandicapping strategies, seemed aware of the impact of their actions on academic performance and are concerned about their professional training. These same students also reported that reflecting on actions that are detrimental to learning is a crucial step toward changing their behavior, enhancing their learning and academic performance and becoming good professionals. It is clear that these data are highly promising, particularly because they were collected from individuals who aspire to be teachers.

The difficulty of individuals assuming responsibility for their failure and evaluating their limitations tends to create considerably worse results than what could have been achieved had they invested proper efforts in performing a task. To improve this situation, individuals must critically analyze their accomplishments, identify the skills that they have mastered and those skills which need to be improved and, most importantly, believe in their ability to achieve the desired success.

The findings of the study show that irrespective of age, gender or course year, students can display behaviors that are unfavorable to learning. Given these results and the paucity of Brazilian publications on the use of selfhandicapping strategies, the need to further research on this topic is evident. In addition to identifying these behaviors, it could be interesting to propose ways to reduce the frequency of their occurrence in the academic setting. It can be expected that once students become knowledgeable regarding what these strategies are and how to minimize their use, they will be more able to modify their behavior during college.

As the sample consisted of students from a pedagogy program, it is essential to consider that these students are preparing to become teachers of children and teenagers who, in turn, could be using the same self-handicapping strategies reported in this study. In addition to benefiting students, it is expected that if college students have a better understanding of these behaviors, they will be able to identify self-handicapping attitudes, guide their students by providing better methods to deal with these attitudes and help them develop behaviors more favorable toward quality learning.

\section{References}

Alter, A., \& Forgas, J. (2007). On being happy but fearing failure: The effects of mood on self-handicapping strategies. Journal of Experimental Social Psychology, 43(6), 947-954.

Berglas, S., \& Jones, E. E. (1978). Drug choice as a selfhandicapping strategy in response to noncontingent success. Journal of Personality and Social Psychology, 36(4), 405-417.

Boruchovitch, E. \& Ganda, D. (2013). Escala de estratégias autoprejudiciais para alunos universitários: validade de construto e propriedades psicométricas. In VI Congresso Brasileiro de Avaliação Psicológica, Maceió, AL.

Coudevylle, G. R., Martin Ginis, K. A., Famose, J., \& Gernigon, C. (2009). An experimental investigation of the determinants and consequences of self-handicapping strategies across motivational climates. European Journal of Sport Science, 9(4), 219-227.

Ferrari, J., \& Tice, D. (2000). Procrastination as a self-handicap for men and women: A task- avoidance in a laboratory setting. Journal of Research in Personality, 34(1), 73-83.

Finez, L. \& Sherman, D. K. (2012). Train in vain: The role of the self in claimed self-handicapping strategies. Journal of Sport and Exercise Psychology, 34(2), 600-620.

Gadbois, S. A., \& Sturgeon, R. D. (2011). Academic selfhandicapping: Relationships with learning specific and general self-perceptions and academic performance over time. British Journal of Educational Psychology, 81(2), 207-222.

Ganda, D. R. (2011). Atribuições de causalidade e estratégias autoprejudiciais de alunos de curso de formação de professores (Disertação de mestrado não-publicada). Universidade Estadual de Campinas. 
Graham, J., Tisher, R., Ainley, M., \& Kennedy, G. (2008). Staying with the text: The contribution of gender, achievement orientations and interest to students' performance on a literacy task. Educational Psychology, 28(7), 757-776.

Harris, R. N., Snyder, C. R., Higgins, R. L., \& Schrag, J. L. (1986). Enhancing the prediction of self-handicapping. Journal of Personality and Social Psychology, 51(6), 1191-1199.

Hendrix, K. S., \& Hirt, E. R. (2009). Stressed out over possible failure: The role of regulatory fit on claimed self-handicapping. Journal of Experimental Social Psychology, 45(1), 51-59.

Hirt, E. R., Deppe, R. K., \& Gordon, L. J. (1991). Self-reported versus behavioral self-handicapping: Empirical evidence for a theoretical distinction. Journal of Personality and Social Psychology, 61(6), 981-991.

Hirt, E. R., McCrea, S. M., \& Boris, H. I. (2003). I know you self-handicapped last exam': Gender differences in reactions to self-handicapping. Journal of Personality and Social Psychology, 84(1), 177-193.

Hirt, E. R., McCrea, S. M., \& Kimble, C. E. (2000). Public self-focus and sex differences in behavioral selfhandicapping. Personality and Social Psychology Bulletin, 26(9), 1131-1141.

Kolditz, T. A., \& Arkin, R. M. (1982). An impression management interpretation of the self-handicapping strategy. Journal of Personality and Social Psychology, 43(3), 492-502.

Lay, C. H., Knish, S., \& Zanatta, R. (1992). Self-handicappers and procrastinators: A comparison of their practice behavior prior to an evaluation. Journal of Research in Personality, 26(3), 242-257.

Leary, M. R., \& Shepperd, J. A. (1986). Behavioral selfhandicaps versus self-reported handicaps: A conceptual note. Journal of Personality and Social Psychology, 51(6), 1265-1268.

Leondari, A., \& Gonida, E. (2007). Predicting academic self-handicapping in different age groups: The role of personal achievement goals and social goals. British Journal of Educational Psychology, 77(3), 595-611.

Martin, A., Marsh, H., \& Debus, R. (2001). Self-handicapping and defensive pessimism: Exploring a model of predictors and outcomes from a self-protection perspective. Journal of Educational Psychology, 93(1), 87-102.

Martin, A. J., Marsh, H. W., Williamson, A., \& Debus, R. L. (2003). Self-Handicapping, defensive pessimism and goal orientation: A qualitative study of university students. Journal of Educational Psychology, 95(3), 617-628.

McCrea, S. (2008). Self-handicapping, excuse making, and counterfactual thinking: Consequences for self-esteem and future motivation. Journal of Personality and Social Psychology, 95(2), 274-292.

McCrea, S., Hirt, E. R., Hendrix, K. L., Milner, B. J., \& Steele, N. L. (2008). The worker scale: Developing a measure to explain gender differences in behavioral self-handicapping. Journal of Research in Personality, 42(4), 949-970.

Prieto, G., \& Muñiz, J. (2000). Um modelo para evaluar la calidad de los tests utilizados em España. Madrid, Espanha: Papeles Del Psicólogo. Recuperado em abril 20, 2013, de http://www.cop.es/tests/modelo.htm

Schraw, G, Wadkins, T., \& Olafson, L. (2007). Doing the things we do: A grounded theory of academic procrastination. Journal of Educational Psychology, 99(1), 12-25.

Schwinger, M., \& Stiensmeier-Pelster, J. (2011). Prevention of self-handicapping: The protective function of mastery goals. Learning and Individual Differences, 21(6), 699-709.

Seli, H., Dembo, M. H., \& Crocker, S. (2009). Self in self-worth protection: The relationship of possible selves and selfprotective strategies. College Student Journal, 43(3), 1-9. Retrieved in November 20, 2012, from http://lawjournals-books.vlex.com/vid/relationship-selvesprotective-strategies-68231899

Smith J. L, Hardy T., \& Arkin R. (2009). When practice doesn't make perfect: Effort expenditure as an active behavioral self-handicapping strategy. Journal of Research in Personality, 43(1), 95-98.

Stipek, D. J. (1988). Motivation to learn: From theory to practice. Englewood Cliffs, NJ: Prentice Hall.

Tice, D. M., \& Baumeister, R. F. (1997). Longitudinal study of procrastination, performance, stress, and health: The costs and benefits of dawdling. Psychological Science, 8(6), 454-458.

Urdan, T. (2004). Predictors of academic self-handicapping and achievement: Examining achievement goals, classroom goal structures and culture. Journal of Educational Psychology, 96(2), 251-264.

Zanatto, R. (2007). Perfil motivacional de alunos de arquitetura: um estudo exploratório (Dissertação de mestrado não-publicada). Universidade Estadual de Londrina.

Zimmerman, B. J. (2006). Enhancing students' academic responsibility and achievement: A social-cognitive self-regulatory account. In R. J. Sternberg \& R. Subotnik (Eds.), Optimizing student success in school with the other three Rs: Reasoning, resilience, and responsibility (pp.179-197). Greenwich, CT: Information Age.

Zimmerman, B. J., \& Schunk, D. H. (2004). Self-regulating intellectual processes and outcomes: A Social cognitive perspective. In D. Y. Dai \& R. J. Sternberg (Orgs.), Motivation, emotion and cognition: Integrative perspectives on intellectual development and functioning (pp.323-350). Mahwah: Lawrence Erlbaum Associates.

Received: July 1, 2013

Final version: October 17, 2013

Approved: November 22, 2013 
